\title{
MEMÓRIA E MELANCOLIA EM ESTUDOS PARA O SEU CORPO DE FABRÍCIO CORSALETTI ${ }^{76}$
}

\section{MEMORY AND MELANCOLY IN ESTUDOS PARA O SEU CORPO BY FABRÍCIO CORSALETTI}

\author{
Elaine Cristina CINTRA ${ }^{77}$
}

\begin{abstract}
RESUMO: Em Estudos para o seu corpo, Fabrício Corsaletti inscreve um sujeito que, através da memória, está sempre tentando se rascunhar no registro e na invenção da escrita poética. Neste processo, a melancolia torna-se uma força fundamental para que o presente se constitua como algo apreensível.
\end{abstract}

PALAVRAS-CHAVE: Poesia brasileira contemporânea; Fabrício Corsaletti; Lírica; Memória.

\begin{abstract}
In Estudos para o seu corpo, Fabrício Corsaletti subscribes a subject that, by the exercise of the memory, is always trying to outline himself, by the register and creation in the poetic writing. In this process, the melancholy is a fundamental strength in order that the present turns itself something apprehensible.
\end{abstract}

KEYWORDS: Brazilian contemporary poetry; Fabrício Corsaleti; Lyrical; Memory

A memória é para aqueles que esqueceram.

Plotino

\section{NAS INTERMITÊNCIAS DOS TEMPOS}

Em Estudos para o seu corpo (2007), livro-coletânea de Fabrício Corsaletti, é possível rastrear a trajetória de um sujeito lírico em constante ebulição que se constitui em várias direções, mas que percorre inevitavelmente um caminho: os movimentos para

\footnotetext{
${ }^{76}$ Uma versão preliminar deste texto foi apresentada na UNESP/São José do Rio Preto, em 2009, em Seminário de teses organizado pelo IBILCE. Segue uma versão revisada.

77 Instituto de Letras e Linguística - Universidade Federal de Uberlândia (UFU) - CEP 38400-000 Uberlândia - MG - Brasil - elcintra@yahoo.com
} 
o passado, percebidos nas suas obsessivas recorrências à memória, lugar onde o eu se inscreve ao voltar para suas paisagens da infância e adolescência. Em uma linguagem contida e essencial, e versos escritos em um suposto coloquialismo nos quais o humor e a ironia são atravessados por uma violência incisiva, a poesia desse autor se realiza na estetização da memória, trazendo para a contemporaneidade uma vivência melancólica como elemento-chave para a constituição lírica.

A atuação da memória como princípio fundante da poética de Corsaletti será constatada em alguns procedimentos reiterativos, como os inúmeros casos de desdobramentos tais como a enumeração, as intersecções e a onipresente aparição do duplo. Por outro lado, essa lírica se faz com uma força de contenção expressa na economia dos processos linguísticos, que estarão melhor representados pela elipse e ironia constantes. Assim, as formas simultâneas e fragmentadas da memória encontram em Corsaletti uma expressão lírica que traz à cena um sujeito melancólico e ambivalente, representativo de um tempo de esvaecimentos.

Fabrício Corsaletti publicou seu primeiro livro, Movediço, em 2001, e o segundo, O sobrevivente, em 2003. Estudos para o seu corpo constitui-se de uma coletânea desses dois livros já publicados e mais dois livros inéditos, História das demolições e o homônimo Estudos para o seu corpo. Os temas que percorrem estas obras são a recorrência ao passado, o desconforto com o espaço citadino, o erotismo, a violência, temas moldados pela tônica de um verso elíptico e coloquial e um humor visceral.

O jornal $O$ Globo, em resenha de 30 de junho de 2007, saudou esta edição da seguinte forma: "pontuação exígua, senso certeiro de imagem e divisão rítmica, além de precisão e aridez no verso, Corsaletti parece radicalizar a poesia do modernismo de primeira hora, ao mesmo tempo que lhe atualiza o léxico e a velocidade de percepção" (BRESSANE, 2008). As relações com a tradição modernista, aliás, são constantes nas leituras da crítica a respeito do autor. Nesta mesma entrevista de $O$ Globo são apontadas afinidades do poeta com os modernos em uma ironia que faz ressoar um olhar reprovador a essa tendência contemporânea. Vale citar para não perder a "piada": "Com as lições de Oswald, Drummond e Bandeira na ponta do lápis, o poeta paulista Fabrício Corsaletti estreia pela Cia. das letras em antologia que atualiza o modernismo - sem ser chato.” (idem). Já Tadeu Sarmento (2008), em seu blog, não recebe tão bem esta relação com os modernos: “o estilo de Fabrício Corsaletti é a soma diluída dos dois principais 
erros de Drummond: o tédio do funcionário público e a melancolia boba das frustrações interioranas do cotidiano".

Essa "melancolia boba", traço que não é exatamente um "erro" de Drummond mas sua expressão de um tempo e um sujeito, traz à tona um dos pontos importantes do estilo de Corsaletti, a melancolia das experiências do cotidiano da lírica moderna, um impasse no qual o sujeito lírico apresenta uma vivência dolorosa de perda e vazio. Esse sentimento do mundo e de si molda-se em uma linguagem despretensiosa e de um vocabulário desconcertantemente simples, evocando um ritmo emoldurado pelas repetidas enumerações e elipses que afirmam esse sujeito sem saída.

Nesta poética da experiência contemporânea de ser, a cidade grande constitui uma imagem importante, pois representa o lugar da solidão, local de deslocamento em que o sujeito não consegue se apropriar de si, precisando sempre recorrer, sem grande sucesso, a um outro eu que ficou no passado. Assim, o eu-lírico sente-se exilado, quer "morar em todas as/casas que vê/ e imagina" (CORSALETTI, 2007, p.28), qualquer uma que o faça sentir-se de volta a si mesmo. Neste sentido, diante da experiência na metrópole, o sujeito lírico parte-se e, para reconstituir uma unidade perdida, volta para outro lugar e outro tempo, em um movimento contínuo de deslocamento e saída de si.

Movediço é o livro que, de maneira privilegiada, apresenta um eu-lírico deslocado de si espacial e temporalmente, e que na cidade não se percebe em sua totalidade, recorrendo à memória para se transportar para longe de si mesmo: "meu pensamento/sempre/em outro lugar" (CORSALETTI, 2007, p.21). O eu-lírico vai se movendo nos interstícios dos espaços da infância e de agora, e nessa tensão constante, $\mathrm{o}$ sujeito se desmantela, o que pode ser notado através das imagens de um corpo partido, em que a sinédoque aponta para partes isoladas e descritas através de um tom grotesco e violento. $\mathrm{O}$ eu arranca uma a uma as unhas da mão para metaforizar a dor da solidão, ou mostra os dentes rangendo de ódio para expressar a raiva incontida, apresentando um corpo-sujeito em total fúria. A presença mais reiterada, no entanto, será a dos olhos, que aparecem fora de foco ("Meu olho fora de foco", p.24), arrepiados ("perdêramos a linguagem,/não tivéramos mais/ que os arrepiados olhos/ do delírio!”, p.24), zoomorfizados ("olhos de gato", "olhos de cachorro"), e que estão em toda parte, vigilantes, representando um sujeito lírico observador, mas imerso no desconforto de sua inépcia existencial. 
$O$ sobrevivente, livro seguinte, traz à cena um eu-lírico com um sentimento inexorável de perda, totalmente desolado, buscando no elemento erótico o consolo para o vazio existencial. Neste livro, o corpo vai se imiscuindo na memória, tornando-se fator decisivo para a busca irrefreável, fragmentada, tentando se reconstituir em sensações e sentidos outrora vividos. O duplo se apresenta aqui, como um eu que se contrapõe ao constituído no presente, vendo-se mais nitidamente através de seu corpo, que se torna um elemento importante para expressar as ambiguidades e dores do sujeito presentes em suas mais íntimas dimensões. Há um movimento de se expor esse corpo até suas entranhas, mesmo que para isto, ele tenha que ser devorado ou dilacerado.

História das demolições imprime uma nova perspectiva para essas questões. A memória aqui é apresentada não como espaço idealizado em que o eu-lírico se vê inteiro, mas como um processo de autodemolição: "lembrar o que quer que seja é inútil" (CORSALETTI, 2007, p.120). Agora, sua presença se configura mais como esquecimento do que como memória propriamente dita. Este movimento de negação reitera o sentimento de pessimismo e melancolia que perpassa a obra e que somente no erotismo encontrará conforto e alívio.

Dessa forma, é sempre entre desdobramentos tensos que a poética de Corsaletti se constitui. A posição crítica percebeu, até agora, que a obra do poeta biparte-se. Para Carlos Machado (2009), a poesia de Corsaletti está dividida em duas direções: na primeira, ele teria "um acerto de contas com a infância e a adolescência"; a partir de Histórias das demolições, o poeta volta-se mais para os problemas que o jovem terá ao enfrentar a cidade grande e deparar-se com a figura feminina. Já Fabiano Calixto (2008) observa em toda a obra a mesma “busca incansável (poética) de 'outros lugares'. Algo um tanto trágico, porém que jamais se vinga que nunca se propõe ao reparo da inevitável rachadura nos vínculos."

É fundamental, ao analisar a obra de Corsaletti, como Carpinejar (2008) percebeu, notar que as ambivalências neste poeta não se encontram somente no possível aspecto duplo do desenvolvimento central de seu tema, mas na dicção ambígua que "parte do sussurro e alcança o grito, que vai da poesia mais realista fundamentada em arrolamentos aos rompantes surrealistas, que trafega da concisão irônica aos versos longos dialogados." 
Corsaletti transita da simplicidade de versos com um sabor de inocência, para a violência explícita que chega ao grotesco, emoldurada por imagens absurdas, palavras soltas, exercícios elípticos hipertrofiados, antíteses e paradoxos inesperados. Assim, da cidade pequena e seu bucolismo terno de uma infância de educação sentimental e aconchego familiar, o sujeito lírico aprende a ver a metrópole com a brutalidade e a velocidade que lhe atordoam e lhe moldam um ritmo perverso. É, portanto, entre a delicadeza dos eflúvios das sensações amorosas às perturbadas imagens de vísceras e entranhas expostas que a poesia deste autor se realiza.

Desse modo, através dos vários exercícios de desdobramentos que são propiciados pela efetiva asserção da memória, o poeta faz emergir uma tentativa de subjetividade em um tempo caracterizado pelo esvaziamento da experiência. Nas dobras e desdobramentos do eu, Corsaletti tenta constituir um sujeito lírico que lhe escapa pela intangibilidade do presente e que termina por ser inscrito melancolicamente no registro poético.

\section{DESRECONTANDO}

A vocação para o desdobramento acompanha também as discussões teóricas sobre a memória. Ao mesmo tempo em que vivemos um momento que privilegia o ato de lembrar, como Huyssen (2000) reitera nos movimentos obsessivos de retorno ao passado através da construção de monumentos, da "musealização" e “automusealização" e dos processos artísticos de autoficção, documentários, entre outros, o presente exime de suas prioridades tudo o que considera anacrônico, que fuja ao instantâneo e à necessidade do novo. As vanguardas artísticas consolidaram paradigmas nos quais o antigo sucumbe à novidade e vê-se, mesmo hoje, na arte, a contaminação desses pressupostos.

Em Tempo passado, ao analisar a guinada subjetiva nos estudos sobre a memória nas últimas décadas, Beatriz Sarlo cita Susan Sontag: "Talvez se atribua valor demais à memória e valor insuficiente ao pensamento" (SONTAG apud SARLO, 2007, p.21). O excesso da memória seria prejudicial a um entendimento e a uma clarificação do passado tão necessários no presente. Apesar disso, Sarlo afirma a força da memória como implacável, e a impossibilidade de se eliminar o passado, o que ocorreria somente “de modo aproximativo ou figurado" (SARLO, 2007, p.10). 
Também Todorov (2000), posiciona-se diante do binômio excesso-apagamento da memória, analisando os vários usos e abusos realizados por seus estudiosos. Sabe-se que as circunstâncias opressivas dos regimes totalitários provocaram o aparecimento dos "militantes da memória" em um movimento de resistência às tiranias do século XX que sistematizaram a apropriação da memória, aspirando controlá-la em seus níveis mais íntimos. Assim, a memória arrecadou para si prestígio com os inimigos do totalitarismo, porque todo ato de reminiscência, por humilde que seja, é associado com a resistência antitotalitária.

Sobre os abusos, Todorov cita o uso do poder no sentido de institucionalizar e apagar determinadas verdades, como a exumação dos corpos nos campos de concentração e a manipulação de fotografias: "a História se reescreve com cada mudança do quadro dirigente e pede aos leitores da enciclopédia que eliminem por si mesmo aquelas páginas convertidas em indesejáveis" (TODOROV, 2000, p.12). Também há de se lembrar que nem todas as memórias são admiráveis, e aquelas que alimentam o espírito de vingança e separação suscitam certas reservas.

Por outro lado, o elogio incondicional da memória e a condenação ritual do esquecimento também seriam, para Todorov, problemáticos, uma vez que a carga emocional desse passado é imensa, o que faz com que não haja uma relativa objetividade em sua análise. A memória, sendo obrigatoriamente uma seleção, articulase com vários outros princípios orientadores: a voluntariedade, o consentimento, a razão, a criação, a liberdade. $\mathrm{Na}$ arte, por exemplo, a memória não se opõe ao esquecimento, mas à invenção.

Diante desse panorama, Todorov (2000, p.29) faz as seguintes perguntas: "existe um modo para distinguir de antemão os bons e os maus usos do passado?" "Como definir os critérios que nos permitam uma boa seleção?" "É possível pensar isso racionalmente?" Para ele, uma boa maneira de distinguir os bons usos da memória seria perguntar-se sobre os resultados desse uso.

Todorov apresenta, nesse texto, a chamada "memória exemplar", que, ao contrário da "memória literal", revisita o passado como algo que provoca uma atuação no presente, que leu e apreendeu sua lição pretérita. Na remissão à memória, seria, então, importante estar atento a alguns pontos. Um deles diz respeito ao fato de que a reincidência excessiva do passado nos permite ignorar o presente. Também, para esse 
autor, os praticantes do "culto à memória" podem usá-la para assegurar para si alguns privilégios na sociedade. Enfim, para Todorov, o culto à memória não é sempre favorável à própria memória:

Sin duda, todos tienen derecho a recuperar su pasado, pero no hay razón para erigir un culto a la memoria por la memoria; sacralizar la memoria es otro modo de hacerla estéril. Una vez restablecido el pasado, la pregunta debe ser: ¿para qué puede servir, y con qué fin? (p. 33).

A lírica moderna e contemporânea liga-se de maneira inexorável à questão. Se o famoso ensaio de Walter Benjamin sobre Baudelaire já discutia a relação memória/esquecimento que o trauma dos tempos modernos causava no poeta e como isto levaria a um esvaziamento da experiência e a consequente devastação da subjetividade, é possível ver no momento atual aquilo que penso ser o revide da memória, que, diretamente ou em suas formas camufladas, impregna a lírica com a sua inevitabilidade.

Em "Traços de memória na poesia brasileira contemporânea", Celia Pedrosa (2000, p.113) explica que a memória na lírica dos dias atuais se dá por uma relação de "tensão entre negatividade e re-insurreição", quase não havendo evocação do passado individual ou coletivo. Além disso, essa estudiosa acredita que "a prática da memória aparece constantemente como objeto da reflexão poética, mas para ter seu valor questionado até a negação.” (p.113).

Pedrosa considera que este movimento de desqualificação da memória é, na verdade, a reiteração de sua presença, mesmo que negativa, invocando-a por "meio da obsessiva desestabilização de seus suportes" (p.120). Assim, haveria uma dessacralização do passado e a memória seria sombra, e como tal estaria sempre presente. Mesmo não explícita, a memória, então, contaminaria a contemporaneidade em seus movimentos imanentes, e, em algumas vezes, como destaca a autora ao citar, por exemplo, o poeta Ítalo Moriconi, em movimentos intertextuais, ou autotextuais aquilo que Paulo Henriques Britto (2000) vai denominar como "memória lida" do poeta que este autor chama de "pós-lírico".

Para Britto (2000), como o conceito de sujeito individual hoje é anacrônico, e o projeto do poeta lírico seria o de forjar um mito de individualidade, não faria sentido 
mais pensar nesse poeta. Neste sentido, a memória vivida, parte importante da constituição deste mito, foi substituída pela memória lida, e a intertextualidade substituiu a experiência.

A visão sombria de Britto corresponde à leitura de Adorno, que vê na lírica moderna a expressão da fratura do sujeito pós-Auschwitz, sujeito este que não poderia mais se representar em seu absoluto e totalidade, como na visão lírica hegeliana. Britto reflete especialmente na incapacidade do gênero, no momento atual, de representar a experiência viva e íntima de um sujeito, uma vez que esse se tornou, como é possível ver em vários momentos da lírica contemporânea, totalmente partido e dilacerado. No entanto, percebe-se nas recentes publicações que o gênero ainda traz para a cena uma tentativa de se constituir esse sujeito. Assim, a lírica não mais seria a representação de um sujeito, mas a representação da tentativa de constituição do mesmo.

É essa perspectiva que se pode vislumbrar na obra de Fabrício Corsaletti. Através da mediação estética da experiência contada, o eu-lírico tenta "desrecontar" sua história, para poder intervir no presente: "estou passando/ pedindo licença/ muito delicadamente/não estou escrevendo/estou desrecontando/ (mas são tantas metáforas)/ a história do meu remorso" (CORSALETTI, 2007, p.25). ${ }^{78}$

A memória, nesse poeta, é o elemento irradiador da experiência que contamina o presente e imana-lhe força. Ao ser perguntado, na entrevista do jornal $O$ Globo, sobre as razões pelas quais a infância sobressai tanto em sua obra, a resposta de Corsaletti foi incisiva: "A infância me parece o lugar onde todas as sensações estão concentradas e além disso me parece infinita, porque é uma experiência encerrada, que já acabou. Ela está lá, mas continua irradiando sua força. Acho que dá pra tirar muita poesia daí". (CORSALETTI, 2008).

Diante deste panorama, o poeta volta-se para o outro, o estranho, das Unheimliche, descrito por Freud como aquele que nos acompanhou desde o início e que pode surgir a qualquer momento. Este outro fantasmal, o si-mesmo passado, invade a obra do poeta principalmente através da memória, lugar onde o eu se vê como outro, em

\footnotetext{
${ }^{78}$ Aqui não é possível deixar de "lembrar" de Drummond em Claro Enigma, quando no poema "Museu da Inconfidência” afirma: “Toda história é remorso” (DRUMMOND, 2006, p.277).
} 
uma tentativa de ressignificação de um tempo diverso, pois o presente é representado como uma persistente melancolia. ${ }^{79}$

Essa memória fragmentada, nostálgica, anunciada em flashes, não muito nítida, invade espaços e tempos de maneira brusca, violentamente desconcertando a ordem do dia e do verso, que é tomado pelas lembranças, traduzindo a quebra de todas as possíveis unidades.

Em Corsaletti, o presente é sempre o momento de um esvaziamento do eu, e o passado é o lugar para o qual o sujeito se dirige para tentar se esboçar. Para Fabiano Calixto, Corsaletti "apura, no plano geral, a ideia de 'outro lugar', como uma utopia delirante, como uma saída para este produto/de séculos/de desamor que é o sujeito, em eterna fuga, sem lugar, sem eldorado, caminhante atemporal sempre em areia movediça" (CALIXTO, 2008).

No poema "Sem acordo" pode-se verificar nitidamente esta duplicidade do eu antigo e do eu presente e como a memória, ao invés de esclarecer, atenua esse descompasso:

\author{
Meu pai fez \\ um papagaio azul \\ e pôs no centro \\ em branco a letra $\mathrm{F}$ - \\ o papagaio do Fabrício. \\ Eu ficava atônito \\ pequeno do seu lado \\ enquanto ele fazia \\ o bicho azul voar. \\ Hoje quando lembro \\ o papagaio meu pai eu do lado \\ é como se olhasse por trás - \\ eles olham o papagaio \\ eu olho os dois e o papagaio \\ e não chegamos a acordo nenhum. (CORSALETTI, 2007, p. 61).
}

\footnotetext{
79 Penso que o termo "melancolia" aqui se aplica principalmente àquela que a definição freudiana apresenta: "desânimo profundamente doloroso, uma suspensão do interesse pelo mundo externo, perda da capacidade de amar, inibição de toda atividade e um rebaixamento do sentimento de auto-estima, que se expressa em auto-recriminações e auto-insultos, chegando até à expectativa delirante de punição." (FREUD, 1992, p.131). Para Freud, reagindo a uma perda ideal do objeto amado, o melancólico teria prazer em se auto-desnudar, mostrando sua miséria em uma atitude ambígua na qual o investimento aplicado ao objeto abandonado recai sobre o ego, e sua perda termina por ser uma perda do ego.
} 
A cena aqui evocada pela memória é a de um eu-menino cuja única ação é essencialmente observar, e que vê seu nome ser inscrito em um papagaio azul que seu pai faz e tenta empinar. A inscrição da letra "F", de Fabrício, identifica o sujeito lírico menino, que, no entanto, está atônito, inerte, apenas a olhar com assombro o efeito da ação do pai. O objeto observado, o papagaio azul com a letra $\mathrm{F}$ branca (outro desdobramento de si mesmo), forma uma cena que é, por sua vez, de maneira especular, observada pelo eu-lírico adulto que, distante temporalmente, tenta resgatar esse tempo em que o F voava em um papagaio azul pelo céu afora ${ }^{80}$. Todos esses desdobramentos estão inscrevendo no texto lírico os vários eus que se olham de maneira especular, sem grande êxito.

A narração do acontecimento privilegia a descrição detalhada dos desdobrados sujeitos líricos que transbordam no texto. Na primeira estrofe, o papagaio é apresentado com suas qualificações: azul, centralizado pela inicial do autor, em síntese, "O papagaio do Fabrício". O nome do autor embaralha as abordagens críticas e aproxima o eu-lírico do eu-autor, conduzindo a discussão para a questão da autobiografia lírica. Para Dominique Combe (2010, p.124), verdade e ficção se apoiam mutuamente, e,

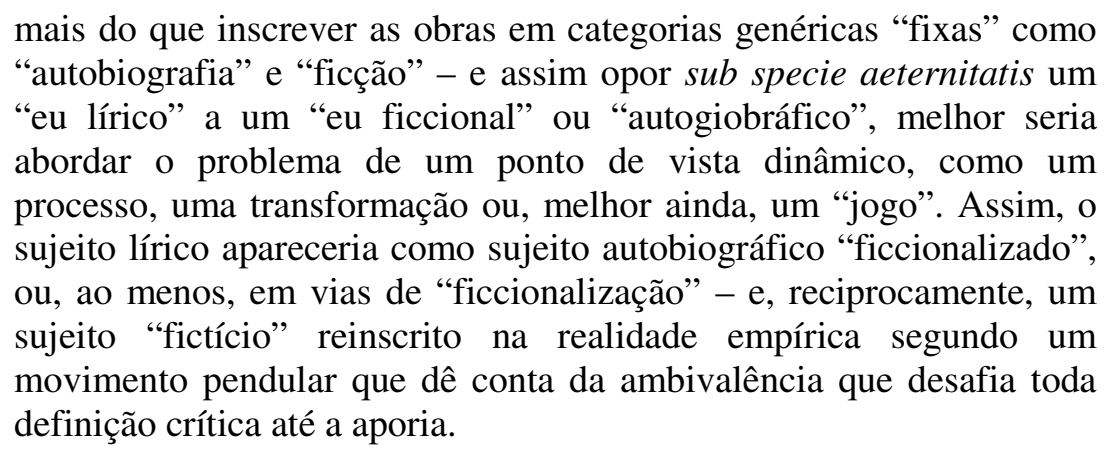

Assim, tal como o papagaio azul confeccionado pelo pai, o F de Fabrício nada mais é que um desdobramento de um eu que se ficcionaliza para se compor, cujas bordas com a realidade estão embaralhadas.

Se na primeira estrofe, a descrição focaliza a representação do papagaio, a segunda descreve o eu-menino qualificado por adjetivos que mostram sua fragilidade, como atônito e pequeno, contrapondo-se à figura de um pai poderoso, capaz, inclusive, de fazer um bicho voar.

\footnotetext{
${ }^{80}$ Para José Emílio Major Neto, há neste poema uma referência ao complexo de Édipo, pois o papagaio com a inscrição do nome fica preso umbilicalmente ao pai. (Aula no ILEEL-UFU, 2010).
} 
O ritmo rápido que impregna as frases em ordem direta, o vocabulário simples e repetido e a falta de pontuação, acompanham a velocidade das imagens e sensações da memória e o enjambement auxilia na formação de um "estado" de memória, no qual o fragmento é o procedimento toante.

$\mathrm{Na}$ terceira estrofe, a ação se volta para o presente e as personagens aglomeram-se no mesmo verso: o papagaio, o pai e o eu antigo embaralham-se pela elipse da vírgula, sob o olhar vigilante do eu atual. Imerso na ação da memória, esse eu que descreve a cena, no entanto, não encontra coincidências entre os outros eus que pululam no texto. O final termina na total dissonância.

No poema "Sem acordo", o poeta revisita esse eu que ficou "por trás", ou seja, fora da cena, observador dos observadores, em uma tentativa frustrada de recuperá-lo, mas o desacordo entre os tempos impede que a sensação anterior seja reeditada e a escrita reitera a impossibilidade de se reviver a infância já consumada. Mais do que evocar uma cena antiga, o poema descreve um acontecimento que provocou um sentimento de desajuste e desconforto no e do eu e que se estende até o presente, mesmo na expressão estética - primeiro, através da representação do papagaio e, agora, na escrita do poema.

No poema anterior a esse, "Meninos soltando pipa", o eu-lírico encontra-se na cidade, observando (novamente) nostalgicamente dois meninos nesta brincadeira, em um domingo silencioso apesar dos grandes volumes dos carros, com a "sensação de que tudo já foi/ ou poderia ter sido/ de outra maneira" (CORSALETTI, 2007, p.60). O presente, então, não foi favorável na resolução desse dilema.

Todos esses desdobramentos, que são a marca da memória, afinal, formam a espinha dorsal da constituição da poesia de Corsaletti. O eu, dividido entre o passado irrecuperável e o presente que não consegue apreender, nunca se sente coeso, uno. Por isso, afasta-se da vida, tornando-se um mero espectador de si mesmo. A memória será um dos elementos usados para que ele se contemple a si mesmo, tentando resgatar o que lhe escapou no momento da experiência, mesmo sabendo que o que procura não está mais no passado e em lugar algum. Não há acordo entre os dois eus, os duplos não se unificam $^{81}$.

\footnotetext{
${ }^{81}$ O "acordo" entre os eus no duplo seria a causa da morte, pois só a morte faria o Eu coincidir consigo mesmo. Para Otto Rank, na obra Don Juan et Le Doublé, o duplo tem exatamente esse poder: impedir a morte do sujeito que ele representa.
} 
Assim, a memória nesse poema aponta, não para a clarificação do presente, mas para a persistência de uma condição melancólica que atravessa toda constituição do eu nesse autor.

Se no poema "Sem acordo" o poeta revisita a infância, em "Memória dos dias comuns", do livro $O$ sobrevivente, há um deslocamento para seu período de formação. Através de quadros compostos por imagens enumeradas de maneira brusca, em que a elipse sustenta um ritmo veloz que impede qualquer tentativa de concatenação, a memória aqui traz uma visão de um passado ao mesmo tempo idílico e grotesco:

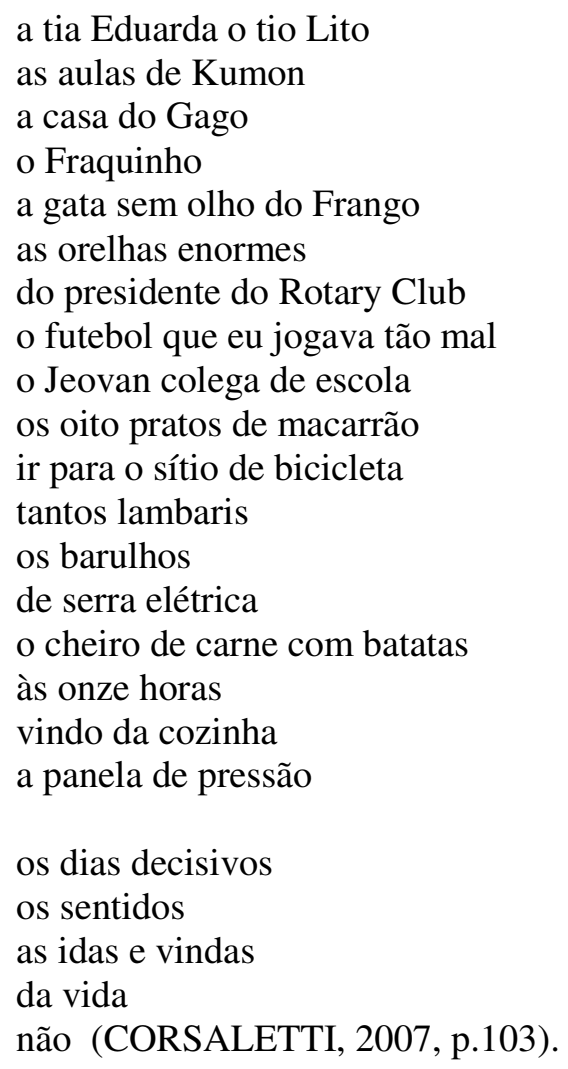

O poema, composto por duas estrofes, o que realça o procedimento dual, está organizado em dois flancos: são enumerados os dias comuns a partir dos elementos que compõem o quadro do cotidiano, incluindo aí parentes, aulas, animais, colegas, esportes, diversões, enfim, cobrindo vastas áreas que darão um panorama amplo de uma vivência passada; no entanto, imiscui-se nesses dados a presença de elementos estranhos, como a gata sem olho, as orelhas enormes do presidente do Rotary Club, os 
oito pratos de macarrão. Em alguns momentos, o mundo é percebido como grotesco, em oposição à imagem idílica presumidamente estabelecida.

Tal como no funcionamento da memória, as imagens vêm e vão de maneira incompleta e sem concatenação lógica, formando um mosaico estranho, peça em que os pedaços soltos compõem uma figura disforme. Sons, anormalidades, um toque de humor, exageros? A memória é registro, mas também é invenção, uma vez que nos escapa a precisão do passado. Para Huyssen (2000, p.37), toda memória é essencialmente transitória, não confiável e passível de esquecimento: "em suma, ela é humana e social". O quadro que é composto, então, na primeira estrofe, não só é desconexo, mas também não confiável; afinal, mais que registro, a memória lírica é invenção que visa um efeito poético - aqui, este efeito caminha irremediavelmente para a melancolia.

Aos poucos, a rememoração impregna-se dos registros dos sentidos, como os barulhos da serra elétrica e o cheiro da carne com batatas, momento forte que passa a ser descrito de maneira mais ampla ocupando quatro dos versos da estrofe, conjugado, através do enjambement, com o barulho da panela de pressão. É interessante notar que a pressão da panela é elemento importante para demonstrar o aumento da tensão que culmina na estrofe seguinte, mais reflexiva e intimista.

$\mathrm{Na}$ segunda estrofe, o poema não mais apresenta a enumeração das imagens do passado, mas uma reflexão sobre este passado e o impacto que ele tem no(s) sentido(s) da vida. O tom é grave, diferentemente da primeira estrofe, e a enumeração não é mais de elementos do cotidiano, mas de situações existenciais. A emoção é contida na frase cada vez mais curta e elíptica e aquela que seria a descrição de um quadro feliz da infância, torna-se uma reflexão amarga do viver.

$\mathrm{O}$ aspecto icônico do poema apresenta um afunilamento mostrando que o ato de rememoração caminhou para um esvaziamento, que terminará com a negação de todas as possibilidades, encerrando não só o ciclo já passado, mas as possibilidades do presente - o "não" fecha as idas e vindas da vida. Novamente, é com violência que Corsaletti encerra o poema que compôs com a memória. O passado não traz ao hoje a resposta ou a salvação. Não há sequer um ponto final, pois o "não" já exclui qualquer possibilidade de continuidade. Recordar, então, para quê? Por ser inevitável. O passado invade o presente, multiplicando os tempos e os viveres. A vida é sempre "vinda". 
Este estado perpétuo de melancolia vai ser acentuado em outro poema, "Tomates", de Movediço, no qual a memória, que já se constitui em um desdobramento do tempo e do eu, apresenta-se duplamente reproduzida, em simulacro:

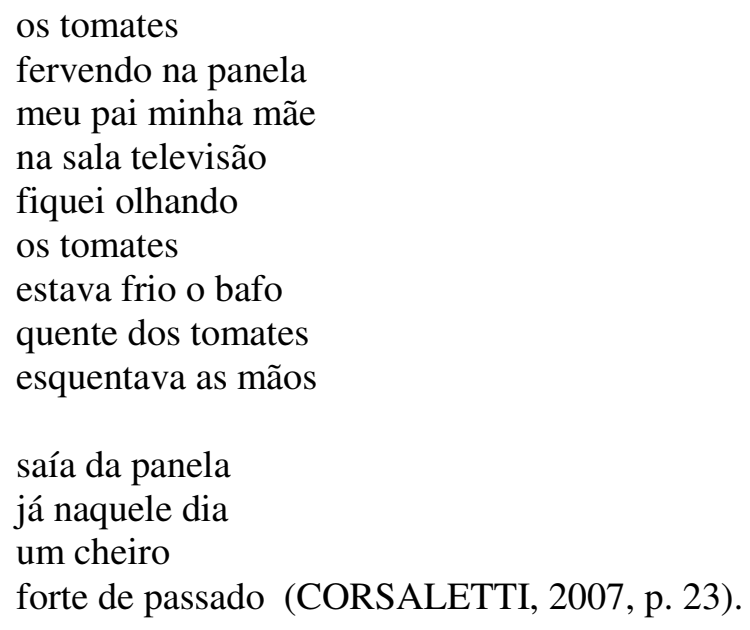

Este poema apresenta a memória de uma cena cotidiana, familiar, de uma simplicidade desconcertante, descrita diretamente em um ritmo rápido. O vocabulário cotidiano forma um jogo ambíguo com as elipses, a falta de pontuação e os enjambements que duplicam os sentidos e tornam o quadro descrito mais complexo do que inicialmente se pode pensar. Assim, "estava frio o bafo" pode também ser lido como "estava frio" e "o bafo quente dos tomates esquentava as mãos". Também o eulírico, através do enjambement, coloca-se como observador de três cenas: o pai e a mãe na sala, a televisão e os tomates. Tais recursos linguísticos do poema representam exatamente o funcionamento da memória, uma vez que tanto na rememoração como no poema, os fatos se justapõem sem distinções nítidas.

O poema segue a estrutura preferida do poeta - duas estrofes, sendo que a primeira apresenta uma descrição mais ampla e a outra uma dimensão mais reflexiva sobre o acontecimento descrito, estrutura que se repete em vários outros poemas do autor. Em "Tomates", figura na primeira estrofe a cena central do poema - a família diante da televisão, enquanto os tomates cozinham na panela e o eu-lírico, dividido entre o frio e o quente do bafo do tomate, observa as sensações que a cena lhe registra no espírito.

A segunda estrofe assimila uma continuidade e conjunção entre os sentidos e o passado. Pelo procedimento da sinédoque (o "cheiro" do passado), o passado retorna 
com toda força pelos sentidos, mantendo no presente um estado de reconhecimento de sua importância. Há, então, um movimento de memória em simulacro, uma vez que a própria cena relembrada relembrava através do cheiro do tomate.

Os tempos, então, encontram-se, no poema, através das evocações do corpo, que os sentidos revivem em instantâneos de sensações. Os olhos, as mãos e o olfato são os elementos que circunstanciarão as reminiscências e que trarão para o poema imagenscorpo que delineiam um passado em fragmento, mas tão nítido que invade os sentidos dos próprios leitores. A memória transcende a recordação de um momento vivido e é usada para reiterar poeticamente o sentimento de melancolia que também se desdobra na repetição da cena já sentida e retomada pelo mesmo sentimento.

Em alguns momentos, no entanto, tal persistência da melancolia vem imersa em cenas inusitadas que elaboram um quadro grotesco, no qual o passado é retomado de maneira ambígua, em uma tensão crescente que termina por explodir nos últimos versos. Tal exercício de memória pode ser verificado no poema "História", do livro História das demolições:

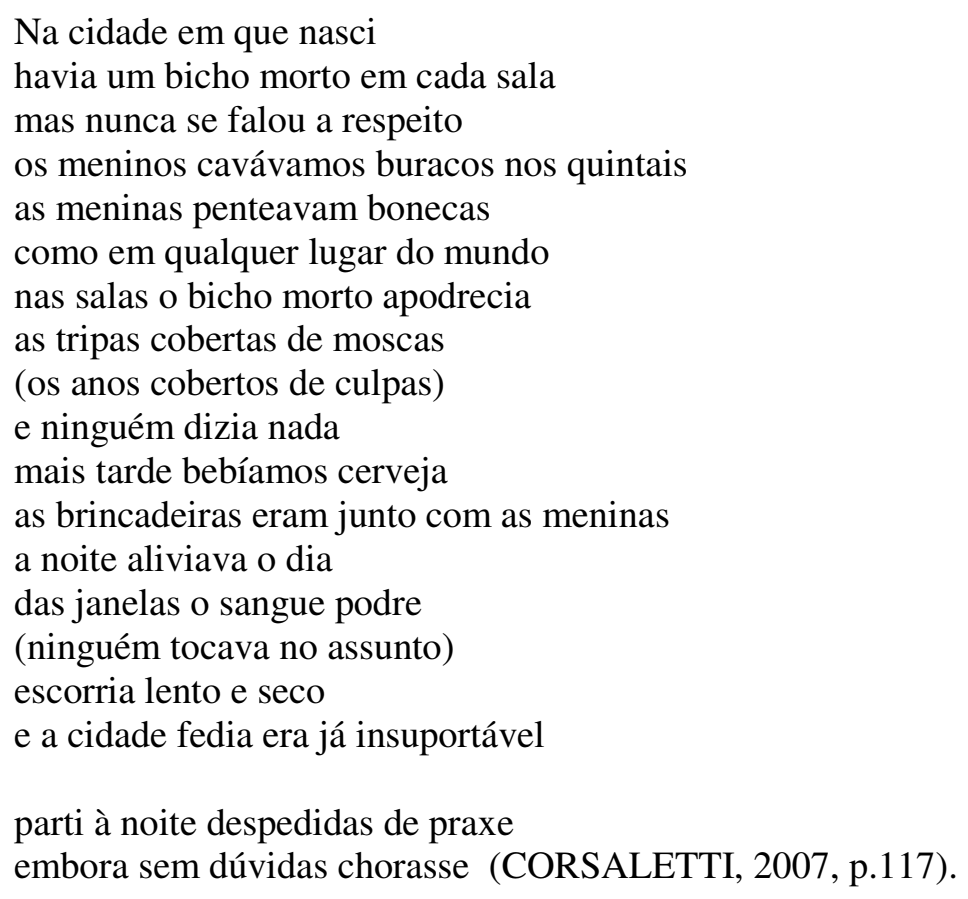

Ao contrário dos poemas anteriores sobre memória, neste a primeira estrofe já apresenta em si toda a experiência dolorida, e até violenta, do passado. Há um misto de sinceridade e cinismo na descrição da cidade que lembra Tebas e sua peste. Aqui, as 
imagens são permeadas por elementos grotescos que cronologicamente narram desde o nascimento até a saída do eu-lírico de sua cidade natal. Os acontecimentos se sucedem intercalados pela descrição dos bichos mortos que apodreciam nas salas, lugares públicos, e infectavam com um cheiro insuportável a cidade, sendo, no entanto, placidamente ignorados. A vida transcorria como se nada estivesse acontecendo, em uma suposta indiferença absurda que lembra as cenas kafkianas. Nesse caso, os parênteses são o recurso estilístico usado para esclarecer aquilo que não está sendo dito explicitamente: a culpa e as omissões que estão infectando a cidade. A imagem da infância perfeita é, então, desmantelada, e a primeira das "histórias das demolições" é a história da demolição do passado idealizado. Nada disso impede, no entanto, que no dístico final, as despedidas sejam dolorosas, apesar que "de praxe".

O poema é estruturado por duas gradações: na primeira transcorre a vida cronológica do sujeito lírico, o seu nascimento, as brincadeiras de infância, a descoberta da sexualidade e a sua saída da cidade. Ao mesmo tempo em que o eu-lírico descobre a vida, a outra gradação paralelamente mostra o apodrecimento do bicho morto nas salas da cidade. O estado do bicho torna-se cada vez mais putrefato, e se no início foi descrito simplesmente como "morto", no decorrer do tempo ele apodrece, as tripas cobrem-se de moscas, o sangue podre escorre até que o cheiro torna-se insuportável. Crescer é apodrecer. As duas linhas gradativas se encontram na saída do eu-lírico da cidade, indicando que uma está intimamente ligada à outra, dimensionando a metáfora, que já vem esclarecida no nono verso: "os anos cobertos de culpa". O bicho/culpa acompanhou todo seu amadurecimento e tornou sua estadia impossível sendo inevitável ir para longe, mesmo que isto lhe custasse. É entre duas linhas tênues que este voltar-se para o passado caminha.

Este poema mostra que a memória, a partir de História das demolições, acentua cada vez mais um olhar crítico, que a toma como pretexto não para reviver um passado, mas para lhe apontar os desacertos e os desconfortos. Assim, a memória será revisionada sempre com um olhar de desconfiança e negação.

No entanto, nesse livro, é no poema homônimo "História das demolições" que o exercício de "destituição" da memória chega a um grau mais radical. Nesse texto, há uma negação da memória, naquele movimento dicotômico que Celia Pedrosa indicou, no qual o esquecimento é justamente o movimento de incidência da mesma: 


\begin{abstract}
A história das demolições a história trágica das demolições não acontece como no cinema a vida não tem trilha no cinema a vida não tem trilha sonora as paredes caem silenciosamente (no máximo a pancada dos martelos) o chão varrido fica melhor (o passado não voltará no ladrilho novo) lembrar o que quer que seja é inútil as imagens da memória são ruins o que ficasse em nós seria a esperança mas o que existe não exige lembrança o que morreu está definitivamente morto não há sequer a vontade de chorá-lo o luto mesmo é impossível (CORSALETTI, 2007, p.120).
\end{abstract}

Nos tempos das demolições, ou das ruínas para usar o termo benjaminiano, a memória foi banida. Lembrar é reviver aquilo que já não tem força para mudar o presente. No entanto, um poema é feito para dizer isto. No uso da preterição, o dizer dizendo que não dirá, a memória é evocada mais uma vez, em um movimento duplo de negação-afirmação, porque lembrar é, de alguma forma, lembrar-se, resgatar-se.

Em um poema em que o vocabulário e as imagens vêm marcados por um tom negativo (“demolições”, "trágica”, "não”, “caem”, "pancada”, "chão varrido”, "inútil”, "ruins”, “morreu”, “morto”, “chorá-lo", "luto”, “impossível”), em que a negação está categoricamente fechando todas as esperanças (que só aparece acompanhada de um verbo subjuntivo, ou seja, em uma possibilidade que é imediatamente negada), a memória é destituída pela sombra e o esquecimento. Sem a memória, não há mais nada, tudo é demolição, trágica demolição.

Mas o poema que nega a memória começa com a palavra "história", propõe-se a registrar justamente a falta desta memória, repetindo, através da anáfora a palavra que remete imediatamente ao ato de documentar o passado. Em outras palavras, o início do poema instaura a memória da destruição da memória. A partir deste início contraditório, imerso em seu duplo, o poeta vai constituindo imagens que compõem o mundo do esquecimento, no qual a memória não tem espaço, ou seja, o tempo das demolições, que termina com o luto, uma das formas de lembrar, e a própria impossibilidade desse mesmo luto: "o luto mesmo é impossível”. Neste panorama enviesado pela demolição da memória, o esvaziamento da experiência previsto por Benjamin se realiza. 
Assim, nesse poema no qual a memória, em um exercício de metamemória, voltase para si mesma e para sua impossibilidade, Corsaletti, na verdade, inscreve-a liricamente para continuar problematizando-a, em um discurso ambíguo e melancólico. É preciso registrar o quanto a memória é incômoda e dolorida e o quanto traz para o presente suas sombras e trevas. Novamente a melancolia percorre os matizes da subjetividade, que só se constitui no desdobramento dos tempos, ao ver-se fora de si, na escrita de sua própria alteridade.

\section{3. "SEM ACORDO"}

A poética de Corsaletti consolida-se na busca da inscrição de um sujeito que tenta, no desdobramento dos tempos, mais especificamente na exploração da memória, elucidar um percurso de sua experiência em uma trajetória lírica. Para isto, circunscreve-se em um movimento de ambiguidade em que o sujeito lírico está sempre tentando se rascunhar na escrita poética através da invenção de si mesmo. Neste processo, a experiência, força fundamental para que o presente se constitua como algo apreensível, emerge em sua lírica, pela rememoração, desdobramento contínuo de um tempo e um sujeito que nunca se unificam. E não há acordo possível que propicie uma unidade nessas instâncias.

Herdeiro desencantado de um Baudelaire atônito que caminhava pela metrópole, o poeta contemporâneo busca até mesmo o esquecimento para ter contato consigo mesmo. Se a experiência não mais é transmissível, a poesia de Corsaletti vem mostrar que na tensão e na alteridade exercidas pela escrita poética, é possível ainda resgatar algumas dimensões do sujeito e da contemporaneidade. Lembrar, então, é sempre o recurso fundamental para se constituir, ou, nas palavras do poeta: "talvez seja o tempo/ de pôr um limite/ mas continuo/ muito assombrado/ com muita coisa/ que anda por ấ”. A sombra do passado, memória fantasmal, mesmo quando categoricamente negada é ainda uma força vital do presente e de sua poesia.

\section{REFERÊNCIAS}

ANDRADE, C. D. de. Poesia completa. Fixação de textos e notas de Gilberto Mendonça Teles. Rio de Janeiro: Nova Aguilar, 2006. 
BRESSANE, R. Meu amor me ensinou a ser simples. Disponível em: http://impostor.wordpress.com/2007/07/14/meu-amor-me-ensinou-a-ser-simples Acesso em 22 de maio de 2008, às $11 \mathrm{~h} 49$.

BRITTO, P. H. Poesia e memória. In: PEDROSA, C. (Org.). Mais poesia hoje. Rio de Janeiro: 7Letras, 2000. p.124-131.

CALIXTO, F. Território lírico: a poesia de Fabrício Corsaletti. Disponível em: http://www.germinaliteratura.com.br/stultifera_navis_set07.htm - Acesso em 22 de maio de 2008, às $12 \mathrm{~h} 04$.

CARPINEJAR, F. Versos de incômoda ressaca. Disponível em: http://flip2007.wordpress.com/fabricio-corsaletti/ - Acesso em 22 de maio de 2008, às $12 \mathrm{~h} 19$.

COMBE, D. A referência desdobrada. O sujeito lírico entre a ficção e a autobiografia. Revista USP, São Paulo, n.84, p.112-128, dez./fev. 2009/2010.

CORSALETTI, F. Estudos para o seu corpo. São Paulo: Companhia das Letras, 2007.

FREUD, S. Luto e melancolia. Tradução Marilena Carone. Novos estudos CEBRAP, São Paulo, n.32, p.128-142, março 1992.

HUYSSEN, A. Seduzidos pela memória: Arquitetura, monumentos, mídia. 2.ed. Rio de Janeiro: Aeroplano, 2000.

MACHADO, C. Poesia.net. Disponível em: http://www.algumapoesia.com.br/poesia2/poesianet219.htm - Acesso em 23 de maio de 2008 , às $19 \mathrm{~h} 19$.

PEDROSA, C. Traços de memória na poesia brasileira contemporânea. In:

(Org.). Mais poesia hoje. Rio de Janeiro: 7Letras, 2000. p.113-123.

RANK, O. Don Juan et le doublé. Paris: Payot, 2001.

SARLO, B. Tempo passado: cultura da memória e guinada subjetiva. Tradução Rosa Freire d'Aguiar. São Paulo: Companhia das Letras; Belo Horizonte: UFMG, 2007.

SARMENTO, T. Blog "quartinho da empregada". Disponível em: HTTP://quartinhodaempregada.blospot.com - Acesso em 22 de maio de 2008, às $10 \mathrm{~h} 49$.

TODOROV, T. Los abusos de la memória. Tradução de Miguel Salazar. Barcelona: Paidós Ibérica, 2000.

Artigo recebido em 27/04/2011

Aceito para publicação em 02/08/2011 